\title{
Transporte espermático e resposta inflamatória uterina na égua após inseminação com diferentes concentrações de espermatozóides*
}

\author{
SANDRA MARA DA ENCARNAÇÃO FIALA \\ Rodrigo Costa Mattos (Orientador - UFRGS)
}

Banca: Monique Albuquerque Lagares (UFMG), Ricardo Macedo Gregory (UFRGS), Cláudio Alves Pimentel (UFPel)

Normalmente, após a cobertura ou a inseminação artificial de éguas, ocorre uma endometrite aguda transitória em resposta ao sêmen e bactérias no útero. O objetivo deste estudo foi verificar se o transporte espermático e a intensidade da reação inflamatória uterina, $2 \mathrm{~h}, 4 \mathrm{~h}$ ou $24 \mathrm{~h}$ após a inseminação com sêmen resfriado, são influenciados pela concentração espermática na dose inseminante. Para tal, foram utilizadas 192 éguas em cio, com folículo dominante $=35 \mathrm{~mm}$, sem crescimento bacteriano e livres de PMNs aos exames uterinos complementares. As éguas foram distribuídas aleatoriamente em grupos e inseminadas com $20 \mathrm{ml}$ contendo $100 \times 10^{6}(\mathrm{n}=30), 500 \times 10^{6}(\mathrm{n}=27)$ ou 1000x10 $(\mathrm{n}=31)$ espermatozóides diluídos em solução de $3 \mathrm{ml}$ de plasma seminal e $17 \mathrm{ml}$ de leite desnatado, refrigerado e armazenado por 18 a 22 horas, ou infundidas com $20 \mathrm{ml}$ de plasma seminal ( $\mathrm{n}=33)$, ou com $20 \mathrm{ml}$ de leite desnatado $(\mathrm{n}=38)$. As éguas foram abatidas duas, quatro ou $24 \mathrm{~h}$ após as inseminações ou infusões. O grupo controle $(n=33)$ não recebeu nenhum tratamento. Os ovidutos foram separados do útero, sendo útero e ovidutos lavados separadamente com PBS. Uma amostra do lavado de cada oviduto foi examinada para contagem de espermatozóides e uma amostra de cada lavado uterino foi utilizada para contagem de leucócitos. Após as lavagens, foi retirada uma amostra de endométrio para exame histopatológico. As éguas inseminadas e infundidas apresentaram reação inflamatória significativamente maior que as éguas do grupo controle, no decorrer das 24 horas. A reação inflamatória foi significativamente maior nas éguas inseminadas que nas infundidas. A reação inflamatória apresentou correlação com a concentração espermática $(\mathrm{r}=0,389)$. O número de éguas apresentando espermatozóides nos ovidutos não foi diferente nos grupos inseminados. Concluiu-se que componentes da dose inseminante provocam uma resposta inflamatória, sendo esta tanto mais severa e de resolução mais rápida, quanto maior for a concentração espermática. Por outro lado, até as quatro horas pós-inseminação, o transporte espermático independe da concentração espermática utilizada

Descritores: égua, reação inflamatória, neutrófilos, endometrite.

Apresentada: 16 janeiro 2004

*Tese de Doutorado n. 33 (Especialidade: Reprodução Animal). 77f. Programa de Pós-graduação em Ciências Veterinárias - UFRGS, Porto Alegre/RS. CORRESPONDÊNCIA: S.M.E. Fiala [fialas@bol.com.br ]. 


\title{
Sperm transport and inflammatory reaction after insemination in mares**
}

\author{
SANDRA MARA DA ENCARNAÇÃO FIALA \\ Rodrigo Costa Mattos (Adviser - UFRGS)
}

Committee: Monique Albuquerque Lagares (UFMG), Ricardo Macedo Gregory (UFRGS), Cláudio Alves Pimentel (UFPel)

\begin{abstract}
A transitory and acute endometritis normally occurs, after natural breeding or artificial insemination (AI), as an inflammatory reaction against semen and bacteria. The aim of this study was to detect if either the sperm transport, or the intensity of inflammatory reaction 2, 4 and 24 hours after AI with cooled semen, depends on the sperm count in the insemination dose. One hundred and ninety two mares in estrus with dominant follicle $=35 \mathrm{~mm}$, free of bacterial growth and without PMNs in uterine smears were used. Mares were randomly assigned to groups and received a $20 \mathrm{ml}$ insemination

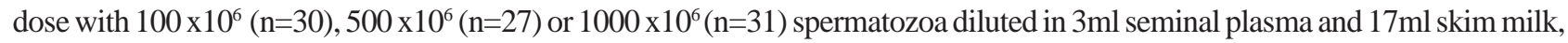
cooled and stored for 18 to $22 \mathrm{~h}$, or a $20 \mathrm{ml}$ seminal plasma $(\mathrm{n}=33)$, or a $20 \mathrm{ml}$ skim milk $(\mathrm{n}=38)$ uterine infusion, being slaughtered 2, 4 or $24 \mathrm{~h}$ later. The control group $(n=33)$ received no treatment. The oviducts were dissected from the uterus and both, uterus and oviducts, were flushed with PBS. A sample from each tubal flush was examined for sperm count and a sample of each uterine flush was examined for leukocytes search and count. After flushes, an endometrial sample was collected for histopathological examination. Inseminated and infused mares showed a significantly greater inflammatory reaction than control group, throughout $24 \mathrm{~h}$. The inflammatory reaction was correlated with sperm count $(\mathrm{r}=0,389)$. The number of mares showing sperm in the oviducts was not different among distinct insemination groups. It was concluded that compounds in the insemination dose induce uterine inflammatory response, that is as more intense and faster, as sperm count increases. On the other hand, during the first four hours after insemination, the sperm transport does not depend on sperm count.
\end{abstract}

Key words: mare, inflammatory reaction, endometritis, neutrophils.

Presented: 16 January 2004

\footnotetext{
**Doctoral Dissertation \# 33 (Field: Animal Reproduction). 77p. Graduate Program in Veterinary Sciences, Faculdade de Veterinária, Universidade Federal do Rio Grande do Sul (UFRGS), Porto Alegre/Brazil. CORRESPONDENCE: S.M.E. Fiala [fialas@bol.com.br].
} 